\title{
VALUASI EKONOMI SUMBERDAYA TERUMBU KARANG DAN MANGROVE DI KAWASAN TAMAN WISATA PERAIRAN (TWP) GILI MATRA, LOMBOK UTARA, NUSA TENGGARA BARAT
}

\author{
Economic Valuation of Coral Reef and Mangrove Resources in The Gili \\ Matra Marine Tourism Park Area, Lombok Utara, Nusa Tenggara Barat
}

\author{
*Siti Hajar Suryawati, Permana Ari Soejarwo, Irwan Muliawan dan Maulana Firdaus \\ ${ }^{1}$ Balai Besar Riset Sosial Ekonomi Kelautan dan Perikanan \\ Gedung BRSDM KP I Lt. 4 \\ Jalan Pasir Putih Nomor 1 Ancol Timur, Jakarta Utara, Indonesia \\ Telp: (021) 64711583 Fax: 64700924
}

Diterima tanggal: 22 Juni 2018 Diterima setelah perbaikan: 8 Nopember 2018

Disetujui terbit: 26 Desember 2018

"email: siti_suryawati@yahoo.com

\begin{abstract}
ABSTRAK
Taman Wisata Perairan Gili Matra merupakan kawasan yang mempunyai nilai ekonomi dan kualitas ekologi yang sangat besar. TWP Gili Matra juga digunakan sebagai sumber penghidupan bagi masyarakat setempat. Penelitian ini bertujuan mengetahui nilai ekonomi total ekosistem terumbu karang dan mangrove di TWP Gili Matra menggunakan metode TEV (Total Economic Value) yang terdiri dari analisis nilai guna langsung menggunakan metode effect on production (EoP) dan travel cost method (TCM), nilai guna tidak langsung menggunakan metode replacement cost dan contingent valuation method (CVM), nilai pilihan menggunakan benefit transfer. Hasil penelitian ini menunjukkan bahwa nilai kegunaan langsung yang meliputi nilai kegunaan sebagai perikanan tangkap sebesar Rp151.130.418/ ha/tahun, nilai kegunaan sebagai penyedia jasa wisata sebesar Rp1.102.165.479/tahun. Nilai kegunaan tidak langsung meliputi nilai kegunaan sebagai pelindung pantai sebesar Rp9.569.065.000/tahun, nilai kegunaan sebagai serapan karbon sebesar Rp150.378,54/tahun serta sebagai nilai kegunaan sosial budaya sebesar Rp4.460.856.979/tahun. Selanjutnya sebagai nilai pilihan untuk penyedia keanekaragaman hayati yaitu untuk ekosistem mangrove sebesar Rp3.043.593.225/tahun serta terumbu karang sebesar Rp10.821.883.500/tahun. Hasil penelitian menunjukan bahwa nilai ekonomi tersebut mempunyai manfaat dan fungsi yang penting sebagai sumberdaya ekonomi maupun ekologi bagi masyarakat maupun pemerintah. Oleh karena itu keberadaan TWP Gili Matra harus tetap dipelihara sebagai aset pembangunan wilayah. Pengendalian dan pengawasan dalam pemanfaatan sumberdaya terumbu karang dan mangrove dapat dilakukan secara terpadu antara pemerintah, masyarakat dan sektor swasta agar ketersediaan sumberdaya terumbu karang dan mangrove di TWP Gili Matra tetap terjaga.
\end{abstract}

Kata Kunci: Gili Matra; sumber daya; terumbu karang; mangrove; valuasi ekonomi

\section{ABSTRACT}

Gili matra tourism park (TWP Gili Matra) is an area with a high value and quality in both ecological and economical. TWP Gili Matra also contributes to living source for local community. This research aims to identify utilization of coral reef and mangrove ecosystem in TWP Gili Matra by using Total Economic Value (TEV) method that consists of direct utilization value analysis using Effect on Production (EoP) method and Travel Cost Method (TCM), while indirect utilization value using Replacement Cost Method and Contingent Valuation Method (CVM), option value analysis using Benefit Transfer method. The results showed that the direct use value including the use value as a capture fishery of IDR 151,130,418/ ha/year, the use value as a tourist service provider of IDR 1,102,165,479/year. Indirect use value including the use value as a coastal protector of IDR 9.569.065.000/year, the use value as carbon uptake of IDR150,378,54/year and the use value as social cultural value of IDR 4,460,856,979/year. Furthermore as selected value for natural biodiversity provider namely for mangrove ecosystem of IDR 3,043,593,225/year and coral reef of IDR 10,821,883,500/year. This result showed that the economic value gives important benefits and functions as economic and ecological resources for society and government. Therefore, it is necessary to preserve the existence of TWP Gili Matra as an asset of regional development. Integrated control and monitoring among government, community and private sector in its utilization will ensure the availability of coral reef and mangrove resources in TWP Gili Matra.

Keywords: marine and fisheries community welfare index; marine and fisheries main actors 


\section{PENDAHULUAN}

Taman Wisata Perairan (TWP) Gili Matra memiliki tiga gugusan pulau-pulau kecil, yaitu Gili Air, Gili Meno dan Gili Trawangan. Gili dalam bahasa Sasak berarti pulau. Penamaan Gili Matra merupakan singkatan dari ketiga pulau tersebut (Meno, Air dan Trawangan). Secara geografis, kawasan TWP Gili Matra berada pada posisi $8^{\circ} 20^{\prime}-8^{\circ} 23^{\prime}$ LS dan $116^{\circ} 00^{\prime}-116^{\circ} 08^{\prime} B T$. Kawasan TWP Gili Matra mempunyai luas $2.954 \mathrm{Ha}$ terdiri dari daratan seluas $665 \mathrm{Ha}$ dan selebihnya adalah perairan laut (Dinas Kelautan dan Perikanan Provinsi, NTB, 2015).

Melalui Keputusan Menteri Kelautan dan Perikanan No. Kep.67/MEN/2009 Pulau Gili Air, Gili Meno dan Gili Trawangan ditetapkan sebagai Kawasan Konservasi Perairan Nasional di Provinsi Nusa Tenggara Barat. Keberadaan TWP Gili Matra bagi masyarakat setempat adalah sangat penting. Hampir semua lapisan masyarakat, baik masyarakat pesisir sampai masyarakat yang tinggal di perkotaan memanfaatkan keberadaan TWP Gili Matra untuk berbagai aktivitas. Mulai aktivitas penangkapan ikan, wisata pantai seperti berenang, snorkeling, diving, kegiatan wisata olahraga air seperti jetski, berjualan makanan dan minuman (cafe), jogging, bersepeda, hingga menikmati sunrise dan sunset (Dinas Kelautan dan Perikanan Provinsi, NTB, 2015). Dalam Kepmen KP No 57 Tahun 2014 disebutkan bahwa ekosistem terumbu karang di kawasan TWP Gili Matra merupakan obyek utama wisata bahari. Luas potensi terumbu karang yang terdapat di TWP Gili Matra adalah 236,25 ha $(101,27$ ha di Gili Trawangan; 58,14 ha di Gili Meno; dan 76,84 ha di Gili Ayer).

Lebih lanjut, Matulis (2014), menjelaskan sebagai sebuah ekosistem, terumbu karang merupakan sumber daya yang tidak mempunyai nilai pasar (non market base). Salah satu proxy bagi nilai ekonomi terumbu karang adalah melalui proxy terhadap nilai produktivitas perikanan. Nilai ekonomi terumbu karang didekati dengan nilai proksi yaitu produktivitas perikanan karang (McCauley, 2006). Sumber daya pesisir dan laut apabila dipandang dari berbagai sisi memiliki peluang yang mampu dijadikan modal dasar dalam upaya pembangunan masyarakat pesisir. Akan tetapi peluang tersebut belum mampu dimanfaat secara maksimal baik oleh Pemerintah maupun sektor swasta (Putera dan Sallata, 2015).
Menurut Adrianto (2006), paradigma baru yang digunakan dalam pengelolaan sumber daya mengacu pada konsep pembangunan keberlanjutan yang menitikberatkan pada keseimbangan antara pertumbuhan ekonomi dan kualitas lingkungan serta sumber daya alam. Konsekuensi logis dari paradigma tersebut menyebabkan adanya perubahan ekosistem yang harus dimasukkan ke dalam pertimbangan pengelolaan, serta termasuk pentingnya mengetahui nilai ekonomi sumber daya sebagai salah satu masukan dalam mengambil kebijakan sehingga pada situasi ini kebutuhan valuasi ekonomi menjadi penting. Upaya pemerintah melakukan rehabilitasi terumbu karang dan konservasi mangrove diantaranya dengan tranplantasi terumbu karang dan penanaman bibit mangrove kembali belum mendapatkan hasil yang sesuai harapan. Gagalnya program tersebut diduga kurang melibatkan peran serta masyarakat sekitar melalui peningkatan dan pengetahuan lingkungan.

Tekanan pembangunan ekonomi sering menimbulkan dilema bagi kelestarian sumber daya alam. Hal ini mengingat, bahwa kebutuhan masyarakat sering tidak ditunjang oleh pengelolaan dan kesadaran masyarakat yang baik. Sehingga penurunan kualitas sumber daya sering dianggap sebagai biaya yang harus dibayar untuk suatu proses pembangunan ekonomi (Muqsith, 2015). Semakin meningkatnya kebutuhan ekonomi berbasis sumber daya alam, akan semakin memberikan tekanan yang tinggi terhadap sumber daya alam itu sendiri. Oleh karena itu penelitian ini bertujuan untuk mengetahui nilai ekonomi ekosistem terumbu karang dan mangrove di TWP Gili Matra yang berasal dari nilai pemanfaatan langsung, nilai pemanfaatan tidak langsung dan nilai non pemanfaatan. Sehingga diharapkan dapat mendukung kebijakan dan pengelolaan TWP Gili Matra yang berkelanjutan.

Penelitian ini dilakukan di TWP Gili Matra, Nusa Tenggara Barat pada bulan SeptemberNovember Tahun 2016. Jenis data yang digunakan dalam penelitian ini adalah data sekunder dan primer. Data sekunder yang dikumpulkan meliputi data demografi, jumlah produksi dan jumlah rumah tangga perikanan tangkap, data pariwisata dan data-data yang terkait dengan potensi sumber daya kelautan dan perikanan di TWP Gili Matra. Data diperoleh dari Kelurahan, BPS (Badan Pusat Statistik), Dinas KPatau KKP (Kementerian Kelautan dan Perikanan), Dinas Pariwisata, serta publikasi ilmiah dari lembaga penelitian dan perguruan tinggi 
(jurnal, prosiding, laporan hasil penelitian, tesis dan disertasi). Data primer yang dikumpulkan meliputi pemanfaatan jasa ekosistem di TWP Gili Matra, karakteristik sosial ekonomi pemanfaat ekosistem di TWP Gili Matra seperti nelayan dan wisatawan yang berkunjung ke TWP Gili Matra meliputi umur, tingkat pendidikan, penghasilan rata-rata per bulan, asal daerah, jumlah biaya yang dikeluarkan untuk berwisata, frekuensi kunjungan, dan jumlah rombongan responden yang datang ke TWP Gili Matra. Informasi yang dikumpulkan terkait nelayan meliputi karakteristik usaha penangkapan, jumlah produksi dan harga ikan hasil tangkapan.

Metode pengumpulan data dilakukan adalah dengan menggunakan teknik survei. Teknik survei ini dilakukan dengan cara melakukan sampling dan wawancara secara langsung dengan responden untuk mengidentifikasi potensi dan kondisi sosial ekonomi terkait pemanfaatan sumber daya yang dilakukan. Survei juga digunakan untuk mengetahui nilai total yang terkandung didalam suatu kawasan. Alat pengumpulan data yang digunakan dalam penelitian ini adalah kuesioner. Kuesioner adalah alat penelitian berupa daftar pertayaan untuk memperoleh keterangan dari sejumlah responden (Suparmoko, 2009). Jumlah sampel responden pada penelitian ini adalah sebanyak 86 responden yang terdiri dari responden nelayan sebanyak 31 orang dan responden wisatawan sebanyak 56 orang. Responden merupakan nelayan yang melakukan penangkapan di sekitar TWP Gili Matra dan wisatawan yang berkunjung ke TWP Gili Matra. Teknik yang digunakan merupakan sampel yang digunakan secara acak. Namun, untuk meminimalisir pencilan (outlier) yang tidak diharapkan dan diperlukan syarat-syarat tertentu. Responden berumur 15 tahun ke atas dan mampu berkomunikasi dengan baik dan diharapkan mampu menjawab pertanyaan secara jujur dan tepat.
Analisis data menggunakan teknik valuasi ekonomi. Teknik ini digunakan untuk menghitung nilai total ekonomi (Total Economic Value/TEV) dari sumber daya perikanan. Nilai ekonomi total merupakan nilai-nilai ekonomi yang terkandung dalam suatu sumber daya alam, baik nilai guna maupun nilai fungsional yang harus diperhitungkan dalam menyusun kebijakan pengelolaannya sehingga alokasi dan alternatif penggunaannya dapat ditentukan secara benar dan tepat sasaran (Spurgeon, 1992; Fauzi, 2000; Nilwan, 2003). Aplikasi dari metode analisis yang digunakan mengacu pada Pearce and Turner (1990), Barton (1994) dan Cesar (2000). Secara matematis, nilai total ekonomi dapat ditulis sebagai berikut:

$$
\begin{aligned}
T E V= & U V+O V+N U V=(D U V+I U V) \\
& +O V+(E V+B V)
\end{aligned}
$$

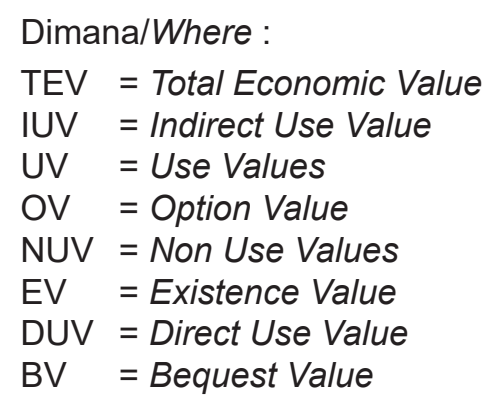

Metode penilaian pada masing - masing jenis fungsi atau manfaat diidentifikasi dari ekosistem terumbu karang dan mangrove diperlihatkan pada Tabel 1 yang menyajikan matrik metode penilaian ekonomi yang digunakan dalam mengestimasi nilai ekonomi sumber daya di wilayah kajian.

Secara rinci uraian masing-masing teknik valuasi adalah sebagai berikut :

Tabel 1. Matrik Metode Penilaian Ekonomi Sumber Daya di TWP Gili Matra.

Table 1. Matrix of the Resource Economic Assessment Method in Gili Matra TWP.

\begin{tabular}{lll}
\hline No & \multicolumn{1}{c}{ Klasifikasi Nilai/ Value Classification } & Metode Penilaian/ Assessment Method \\
\hline 1 & $\begin{array}{l}\text { Nilai guna langsung/Direct Use Values } \\
\text { a. Nelayan Tangkap/ Catching Fishers }\end{array}$ & Effect on Production (EOP) \\
$\begin{array}{l}\text { b. Wisata Pantai/ Beach Tourism } \\
2\end{array}$ & $\begin{array}{l}\text { Nilai guna Tak Langsung/Indirect Use Values } \\
\text { Fungsi Perlindungan Fisik/ Physical Protection } \\
\text { Function }\end{array}$ & Replacement cost \\
& $\begin{array}{l}\text { Nilai Sosial/ Social Value } \\
\text { 3. }\end{array}$ & Nilai Non Manfaat/Non-Use Values \\
\hline & Nilai Pilihan/Option Value & Benefit Transfer \\
\hline
\end{tabular}




\section{a. Effect on Production (EoP)}

Valuasi ekonomi terhadap sumber daya mangrove dilakukan dengan menggunakan pendekatan EoP. Pendekatan ini merupakan pendekatan yang integratif antara aliran ekologi dan aliran ekonomi. Hal ini karenakan lebih fokus pada perubahan aliran fungsi ekologis yang memberikan dampak pada nilai ekonomi sumber daya alam yang dinilai. Hufschmidt et al. (1983) dalam Adrianto (2006), memberikan beberapa langkah analisis integrasi ekologi-ekonomi dalam konteks metode EoP sebagai berikut: Pertama, mengidentifikasi input sumber daya, output (produksi sumber daya) dan residual sumber daya dari sebuah kebijakan/ kegiatan; Kedua, melakukan kuantifikasi aliran fisik dari sumber daya; Ketiga, melakukan kuantifikasi keterkaitan antar sumber daya alam; Keempat, melakukan kuantifikasi aliran dan perubahan fisik ke dalam terminologi kerugian dan manfaat ekonomi. Salah satu teknik yang bisa dilakukan adalah dengan menggunakan pendekatan residual rent.

Residual Rent didefinisikan sebagai perbedaan antar biaya faktor produksi dan nilai panen dari sumber daya alam. Residual rent dapat dilihat sebagai kontribusi sistem alam atau faktor pendapatan (Factor Income) terhadap nilai ekonomi total:

$P V$ residual rent model $=\frac{\sum_{t=0}^{T} \frac{B_{t}-C_{t}}{(1+r)^{t}}}{L}$

Dimana/Where;

$\mathrm{PV}=$ Nilai Sekarang/Present Value

$\mathrm{Bt}=$ Manfaat bersih dari sumber daya kawasan/ Net benefits of regional resources

$\mathrm{Ct}=$ Biaya produksi/Production cost

$\mathrm{t}=$ Jumlah tahun regresi nilai/Number of years value regression

$\mathrm{T}=$ Jumlah total tahun/Number of years

$r=$ Tingkat diskon riil/Discount level

$\mathrm{L} \quad=$ Luas kawasan sumber daya/ Resource Area

\section{b. Travel Cost Method (TCM)}

Metode ini digunakan untuk menghitung nilai ekonomi suatu kawasan wisata melalui estimasi rata-rata permintaan terhadap kunjungan wisata. Pendekatan ini menganggap bahwa biaya perjalanan serta waktu yang dikorbankan wisatawan untuk menuju objek wisata tertentu. Fungsi permintaan atas kunjungan wisatawan individual menurut Grigalunas dan Congar (1995) diformulasikan sebagai berikut:

$$
\ln V_{i}=\beta_{0}-\beta_{1} \ln T C_{i}+\beta_{2} \operatorname{LnINCi}
$$

Dimana/Wehre :

Vi $\quad=$ Trip kunjungan individu ke-i/Individual visit trip

$\mathrm{TCi}=$ Biaya perjalanan individu ke-i/individual cost trip

$\mathrm{INCi}=$ Pendapatan individu/Individual income

Bo $\quad=$ Nilai konstanta dari model/Model constant value

$\beta 1, \beta 2=$ Koefisien regresi masing-masing variabel $/$ Regresion coeficient of each variabel

In = Fungsi logaritma natural untukmengubah persamaan non linier menjadi persamaan linier/Natural logaritm function to change non linier equation to linier equation.

Dengan teknik regresi sederhana (ordinary least square), maka parameter $\beta 0, \beta 1, \beta 2$, dapat diestimasi. (catatan paramater TC diharapkan negatif, dan INC diharapkan positif). Kemudian surplus konsumen rata-rata individu dapat diestimasi dengan menggunakan persamaan:

$$
C S_{i}=\frac{-V_{i}}{\beta_{i}}
$$

\section{Dimana/Where:}

$\mathrm{CSi}=$ Surplus konsumen/Consumen Surplus

$\mathrm{Vi}=$ Tingkat kunjungan individu/Level of individual visiting

$\beta_{1}=$ Nilai parameter regresi untuk biaya perjalanan/Regretion parameter value for travel cost

Nilai ekonomi lokasi rekreasi (total consumers surplus) kemudian dapat diestimasi dengan mengadakan nilai surplus konsumen rata-rata individu.

$$
T C S=C S i+V_{t}
$$

Dimana/Where:

TCS $=$ Surplus konsumen total/Total Consumers Surplus

$\mathrm{CSi}=$ Surplus konsumen/Consumers Surplus

$\mathrm{V}_{\mathrm{t}}=$ Total kunjungan pada tahun analisis (tahun $\mathrm{ke}-\mathrm{t}$ )/Total visits in the year of analysis (year $t$ ) 


\section{c. Replacement Cost Method (RCM)}

Metode RCM digunakan untuk menilai fungsi ekosistem mangrove yang mempunyai fungsi sama seperti pelindung pantai atau penahan gelombang (buffer zone). Biaya rehabilitasi per hektar mangrove dapat digunakan sebagai proksi bagi replacement cost sebagai berikut:

$$
I U V=C r \times M
$$

\section{Dimana/Where:}

IUV = Nilai penggunaan tidak langsung/Indirect Use Values; buffer zone

$\mathrm{Cr} \quad=$ Biaya rehabilitasi mangrove per hektar atau $\mathrm{m}^{2} /$ Mangrove rehabilitation cost per hectare or $m^{2}$

$\mathrm{M} \quad$ = Luas hutan mangrove $\left(\right.$ ha atau $\left.\mathrm{m}^{2}\right) /$ Mangrove area

\section{d. Contingent Valuation Method (CVM).}

Analisis CVM menggunakan perhitungan Total Benefit sebagai analisis dasar untuk menghitung Willingness To Pay (WTP). Hal ini digunakan untuk mendapatkan perkiraan hubungan antara WTP (nilai keberadaan sumber daya) dengan karakteristik responden. Kesediaan untuk membayar adalah jumlah maksimum yang bersedia dibayarkan seseorang untuk menghindari terjadinya penurunan kualitas sumber daya alam dan lingkungan (Fauzi, 2004). Formula yang digunakan yaitu sebagai berikut:

$$
W T P_{i}=\beta_{0}+\sum_{i=1}^{n} \beta_{i} X_{i}
$$

\section{Dimana/Where:}

$$
\begin{aligned}
\mathrm{WTP}_{\mathrm{i}}= & \begin{array}{l}
\text { Kemampuan membayar pengguna } \\
\text { terhadap suatu sumber daya/User pay } \\
\text { ability to resources }
\end{array} \\
\mathrm{X}_{\mathrm{i}}= & \begin{array}{l}
\text { Parameter penjelas ke }-\mathrm{i} / \text { Requairment } \\
\text { paremeter }
\end{array} \\
\mathrm{N}= & \text { Jumlah besaran sampel/Number of } \\
& \text { sampel } \\
\mathrm{i}= & \text { Jumlah variabel/Number of variabel } \\
\beta_{\mathrm{O}}= & \text { Nilai konstanta dari model/Model } \\
& \text { constant value } \\
\mathrm{Bi}= & \text { Koefisienregresimasing-masingvariabel } \\
& \text { ke }-\mathrm{i} / \text { Regresion coeficient of each } \\
& \text { variabel }
\end{aligned}
$$

Pada persamaan 7 , dinormalisasikan agar menyesuaikan bentuk data yang telah dikumpulkan. Bentuk data ordinal seperti pengalaman kerja, usia dan tingkat pendidikan kemudian ditransformasi, sehingga mengharuskan digunakan regresi logaritma ganda. Hasil persamaan berdasarkan regresi logaritma berganda dilakukan dengan tingkat kepercayaan 95\% (Yaping, 1999). Adapun bentuk persamaannya yaitu sebagai berikut:

$$
\begin{aligned}
\text { LnWTP }= & \alpha+b_{1} \frac{1}{n} \sum_{i=1}^{n} \operatorname{Ln} A+b_{2} \frac{1}{n} \sum_{i=1}^{n} \operatorname{LnE}- \\
& +b_{3} \frac{1}{n} \sum_{i=1}^{n} \operatorname{LnXP}+b_{4} \frac{1}{n} \sum_{i=1}^{n} \operatorname{LnI} \ldots(8)
\end{aligned}
$$

$$
\begin{aligned}
& \text { Dimana/Where: } \\
& \text { WTP = Nilai Kesediaan Membayar/WillingnessTo Pay } \\
& \alpha \quad=\text { Konstanta/Constant } \\
& \text { b } \quad=\text { Konstanta model/Model constant } \\
& \mathrm{n} \quad=\text { Jumlah besaran sampel/Number of sampel } \\
& \mathrm{i}=\text { Jumlah variabel/Number of Variabel } \\
& \text { A = Usia Responden/Age of respondent } \\
& \mathrm{E} \quad=\text { Tingkat Pendidikan/Education level } \\
& \mathrm{XP} \quad=\text { Pengalaman Usaha/Experience working } \\
& \text { I = Pendapatan per tahun/Annual income } \\
& \text { In = Fungsi logaritma natural untuk mengubah }
\end{aligned}
$$

Grigalunas and Congar (1995) menggunakan untuk data yang memiliki nilai sebaran yang relatif seragam, dengan interval tidak terlalu besar. Sedangkan untuk memudahkan analisis data dapat digunakan metoda yang digunakan oleh Yaping (1999). Tahap terakhir dalam teknik CVM adalah mengagregatkan rataan yang diperoleh pada tahap tiga. Proses ini melibatkan konversi dari data rataan sampel ke rataan populasi secara keseluruhan. Salah satu cara untuk mengkonversi ini adalah dengan mengalikan rataan sampel dengan jumlah rumah tangga di dalam populasi $(\mathrm{N})$.

\section{e. Benefit Transfer}

Metode benefit transfer yang juga sering disebut sebagai metode sekunder dalam melakukan valuasi sumber daya alam dan lingkungan. Metode ini digunakan untuk menduga 
nilai ekonomi sumber daya alam dan lingkungan dengan cara meminjam hasil studi atau penelitian di tempat lain yang mempunyai karakteristik dan tipologinya sama atau hampir sama.

Penggunaan benefit transfer harus memperhatikan: 1) Nilai manfaat langsung dan nilai manfaat tidak langsung yang kadang kala nilainya di berbagai hasil studi berbeda; 2) Diperlukan deskripsi kualitatif dalam analisis yang akan disusun; 3) Proyek besar atau dengan dampak lingkungan besar atau proyek kecil dengan dampak lingkungan yang serius, memerlukan alat analisis yang lebih akurat, dan dalam hal ini lebih diperlukan metode primer dari sekedar benefit transfer; 4) Perlu dilakukan penyesuaianpenyesuaian dikarenakan kebanyakan kajian dilakukan di negara maju. Penyesuaian yang perlu dilakukan diantaranya adalah pendapatan per orang, hak milik, harga tanah, institusi, budaya, iklim, SDA, dan lain-lain (Shrestha dan Loomis, 2003)

\section{NILAI EKOLOGI TWP GILI MATRA}

Kawasan TWP Gili Matra memiliki potensi sumber daya alam yang tinggi diantaranya berupa biota laut baik flora maupun fauna daratan. Dari sisi sumber daya ikan karang yang berada di kawasan TWP Gili Matra cukup tinggi dimana biomassa ikan karang berkisar antara 541,85 $\mathrm{kg} / \mathrm{ha}$ hingga 818.,3 kg/ha (Dinas Kelautan dan Perikanan Provinsi NTB, 2015). Dari sensus visual yang dilakukan oleh Suharti, (2014), ikan karang yang teridentifikasi sebanyak 84 spesies dan 16 suku. Sementara itu, dari sisi vegetasi daratan yang dijumpai merupakan vegetasi yang dianggap tumbuh secara alami seperti asam laut (Temarindus indica); waru laut (Hibiscus tiliaceus); ketapang (Terminalia cattapa) dan lainnya, serta vegetasi yang sudah diusahakan oleh masyarakat setempat seperti kelapa (Cocos nucifera); bambu (Bambusa sp); Pisang dan tanaman pertanian lainnya. Fauna atau satwa liar yang dijumpai antara lain jenis burung daratan dan itik liar (Dinas Kelautan dan Perikanan Provinsi NTB, 2015). Luas potensi terumbu karang yang terdapat di TWP Gili Matra adalah 448,76 $\mathrm{Ha}$, dengan rincian; 192,96 Ha di Gili Trawangan,118,95 Ha di Gili Meno dan 136,85 Ha di Gili Air (Dinas Kelautan dan Perikanan Provinsi NTB, 2015). Menurut data sebaran terumbu karang tahun 2014 terdapat 109 jenis karang batu yang merupakan anggota dari 44 marga dan 14 famili. Jenis terumbu karang di perairan Gili Matra adalah jenis karang lunak dan karang keras. Karang lunak yaitu Heliophora sp dan Labophyelia sp, Karang keras yaitu Anacropora matthai, Seriatopora hystrix (Suharti, 2014). Sementara itu menurut (Kementerian Kelautan dan Perikanan, 2015) terdapat juga jenis Millephora sp, Anthipathes sp dan Monthipora sp, dan terdapat karang meja Acropora hyacinthus dan Acropora clathrata (Suharti, 2014). Berdasarkan ke tiga wilayah Gili tersebut jumlah spesies tertinggi terdapat di Gili Air sebanyak 49 jenis dan Gili Meno sebanyak 38 jenis karang.

Pada kawasan TWP Gili Matra terdapat 8 jenis pohon mangrove yang tergolong dalam 8 famili yaitu jenis-jenis Bruguiera cylindrica, Sonneratia alba, Excoecaria agallocha, Pemphis acidula, Avicennia alba, Avicennia marina, Rhizopora stylosa dan Lumnitzera racemosa. Spesies Avicennia marina mendominasi di Gili Meno dengan substrat berpasir.

Persentase tutupan mangrove secara keseluruhan di wilayah Gili Matra berkisar antara $49.02 \%$ hingga $70.49 \%$ yang terletak di kawasan Gili Trawangan. Berdasarkan klasifikasi standar kualitas degradasi hutan mangrove melalui Keputusan Menteri Lingkungan Hidup No. 201 tahun 2004, hutan mangrove di Pulau Gili Meno berada dalam kategori cukup baik. Danau air asin yang terdapat di Pulau Gili Meno dimanfaatkan sebagai objek wisata dan telah dikapling oleh pihak swasta.

\section{NILAI EKONOMI TWP GILI MATRA}

Nilai ekonomi dari ekosistem terumbu karang dalam penelitian ini dibatasi pada aktivitas penangkapan ikan. Nelayan di Kawasan Gili Matra pada umumnya menggunakan berbagai jenis alat tangkap seperti jaring, pancing dan bubu. Lokasi penangkapan berada di sekitar Gili Matra. Sementara itu lokasi sentra nelayan pada kawasan konservasi Gili Matra yaitu berada di Pulau Gili Air.

Penghitungan nilai ekonomi manfaat sumber daya ikan pada ekosistem terumbu karang dengan menggunakan pendekatan fungsi linear. Fungsi linear mengasumsikan terjadinya hubungan yang tetap antara variabel yang diduga $(Y)$ dengan variabel penduga $(X)$. Secara rinci hasil nilai variabel dalam fungsi produksi di kawasan konservasi Gili Matra pada tahun 2016 diperlihatkan pada Tabel 2. 
Tabel 2. Nilai Rata-Rata Variabel dalam Fungsi Produksi di Kawasan Konservasi Gili Matra, 2016. Table 2. Average Variable Values in Production Functions in the Gili Matra Conservation Area, 2016.

\begin{tabular}{|c|c|c|c|}
\hline $\begin{array}{l}\text { Variabel/ } \\
\text { Variable }\end{array}$ & $\begin{array}{l}\text { Keterangan/ } \\
\text { Remaks }\end{array}$ & $\begin{array}{l}\text { Nilai Rata-rata/ } \\
\text { Avarage }\end{array}$ & $\begin{array}{l}\text { Standar Deviasi/ } \\
\text { Standard Deviation }\end{array}$ \\
\hline $\mathrm{Y}$ & $\begin{array}{l}\text { Rata-Rata Produksi (Kg/tahun)/ Production } \\
\text { Average (Kg/years) }\end{array}$ & 717 & 331 \\
\hline $\mathrm{X} 1$ & Rata-rata Harga $(\mathrm{Rp} / \mathrm{Kg}) /$ Cost Average & 89,921 & 68,119 \\
\hline $\mathrm{X} 2$ & $\begin{array}{l}\text { Rata-rata Pendapatan (Rp/tahun)/Income } \\
\text { Average (IDR/years) }\end{array}$ & $27,195,097$ & $17,519,911$ \\
\hline $\mathrm{X} 3$ & $\begin{array}{l}\text { Rata-rata Lama Pendidikan (Tahun)/ } \\
\text { Education Average (years) }\end{array}$ & 6 & 4 \\
\hline $\mathrm{X} 4$ & Rata-rata Umur (tahun)/Age Average (years) & 43 & 12 \\
\hline $\mathrm{X} 5$ & $\begin{array}{l}\text { Rata-rata Jumlah Anggota Keluarga (Jiwa) } \\
\text { Number of family average }\end{array}$ & 4 & 1 \\
\hline $\mathrm{x} 6$ & $\begin{array}{l}\text { Rata-rata Ukuran Armada (GT)/Fleet size } \\
\text { average (GT) }\end{array}$ & 2 & 1 \\
\hline $\mathrm{X} 7$ & $\begin{array}{l}\text { Rata-rata jumlah trip (Trip/Tahun)/trip } \\
\text { average(trip/years) }\end{array}$ & 261 & 65 \\
\hline $\mathrm{x} 8$ & $\begin{array}{l}\text { Rata-rata Jumlah Alat Tangkap (Unit)/Fishing } \\
\text { gear average(units) }\end{array}$ & 5 & 3 \\
\hline X9 & $\begin{array}{l}\text { Rata-rata Pengalaman usaha (Tahun)/ } \\
\text { Average of business experient (years) }\end{array}$ & 23 & 13 \\
\hline
\end{tabular}

Keterangan/Remaks : $\mathrm{N}=31$

Sumber:Data Primer diolah, 2016/Source: Primary Data Processed, 2016

Berdasarkan Tabel 2 diketahui bahwa rata-rata produksi tahunan nelayan yang beroperasi di sekitar terumbu karang adalah 717 $\mathrm{Kg} /$ tahun. Rata-rata trip atau perjalanan per tahun adalah 261 trip atau perjalanan, sehingga dapat diketahui produksi rata-rata per trip atau perjalanan adalah $2,75 \mathrm{Kg}$. Nelayan yang berada di Kawasan Konservasi Gili Matra pada umumnya melakukan penangkapan hampir setiap hari kecuali pada hari Jumat. Nelayan karang bersifat one day fishing atau menangkap ikan pulang hari. Lamanya waktu penangkapan berkisar antara 4 sampai dengan 8 jam per trip atau perjalanan. Dari faktor harga, rata-rata yang diterima oleh nelayan adalah Rp89.921/Kg. Kondisi ini menunjukkan bahwa sumber daya ikan (jenis ikan) pada ekosistem terumbu karang memiliki nilai jual yang sangat tinggi. Untuk nilai rata-rata ikan jenis pelagis hanya berkisar Rp20.000/kg. Beberapa jenis ikan di kawasan Gili Matra yang memiliki nilai tinggi diantaranya adalah kerapu khususnya jenis sunu merah (Dinas Keluatan dan Perikanan Provinsi NTB, 2015).

\section{NILAI KEGUNAAN LANGSUNG Sumber daya PESISIR DAN LAUT TWP GILI MATRA}

\section{a. Manfaat Terumbu Karang Untuk Perikanan Tangkap}

Untuk menghitung nilai manfaat secara langsung adalah dengan pendekatan surplus bagi konsumen. Berdasarkan hasil survei lapangan rata-rata usia responden diketahui 43 tahun dan rata-rata lama pengalaman usaha adalah 23 tahun. Hal ini menunjukkan bahwa pilihan menjadi nelayan telah dilakukan sejak usia relatif muda atau usia produktif. Ketergantungan terhadap sumber daya perikanan bagi masyarakat di sekitar TWP Gili Matra sangat tinggi dan telah berlangsung lama. Menurut As'ad (2004), umur merupakan salah satu faktor yang dapat menentukan prestasi kerja, hal ini dikarenakan manusia memiliki batas kemampuan untuk bekerja. Semakin meningkat umur seseorang semakin besar penawaran tenaga kerjanya. Selama masih dalam usia produktif, semakin tinggi umur seseorang, semakin besar tanggung 
jawabnya yang ditanggung, meskipun pada titik tertentu penawaran akan menurun seiring dengan usia yang makin bertambah (Pujiyono, 2013).

Hasil analisis regresi terhadap aktivitas penangkapan ikan pada ekosistem terumbu karang di TWP Gili Matra, diperoleh fungsi permintaan sebagai berikut:

$$
\begin{aligned}
\operatorname{Ln} Q= & 5,92-0,95 \times 1+0,51 \times 2+0,071 \times 3+ \\
& 0,295 \times 4+0,065 \times 5+0,010 \times 6+0,23 \times 7 \\
& +0,011 \times 8+0,002 \times 9
\end{aligned}
$$

Hal ini menunjukkan bahwa semua variabel yang diujikan berbanding lurus dengan fungsi permintaan yang diketahui dari semua nilai positif pada koefisiennya. Fungsi tersebut kemudian dilakukan estimasi terhadap nilai ekonomi sumber daya perikanan dengan menghitung besarnya nilai surplus bagi konsumen (CS). Nilai total kesediaan membayar (U) setiap nelayan di TWP Gili Matra diketahui sebesar Rp1.926.525.757/tahun, sedangkan untuk nilai yang dibayarkan konsumen (PQ) atau harga batas konsumen adalah Rp67.323/ Kg. Dengan demikian dapat diketahui nilai surplus bagi konsumen (CS) sebesar Rp1.878.261.257/ pelaku usaha perikanan. Secara rinci kurva surplus bagi konsumen terhadap permintaan ikan di Kawasan Konservasi Gili Matra disajikan pada Gambar 1.

Luas kawasan terumbu karang yang ada di TWP Gili Matra diketahui seluas 8.016,21 ha (Kementerian Kelautan dan Perikanan, 2015) sementara itu jumlah total populasi nelayan pada kawasan tersebutsebanyak 292 orang. Berdasarkan informasi tersebut maka dapat diketahui bahwa nilai total manfaat langsung sumber daya ikan karang di TWP Gili Matra sebesar Rp151.130.418/ha/ Tahun. Pada Gambar 2 diperlihatkan kurva fungsi permintaan Effect On Production (EOP) aktifitas penangkapan ikan di TWP Gili Matra.

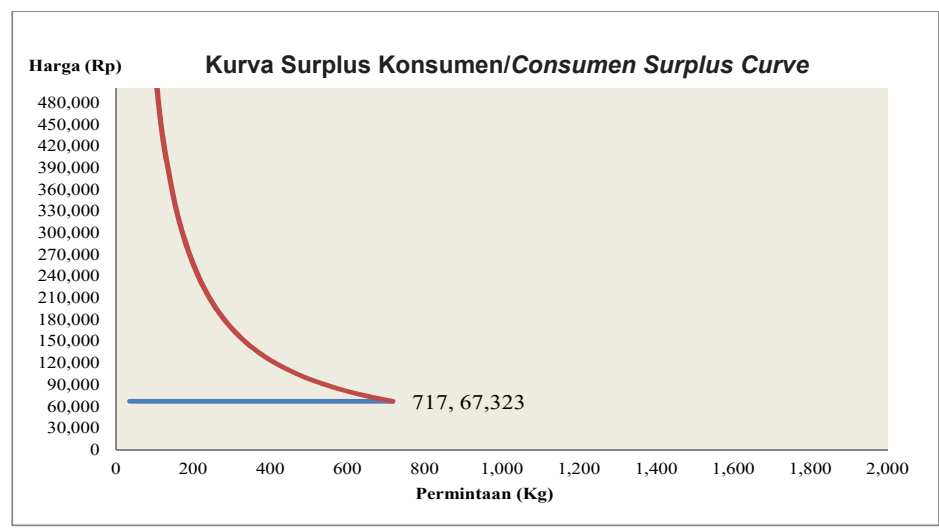

Gambar 1. Kurva Surplus Bagi Konsumen Aktifitas Penangkapan Ikan Karang di Kawasan Konservasi Gili Matra.

Figure 1. Surplus Curve for Consumers of Coral Fishing Activities in the Gili Matra Conservation Area.

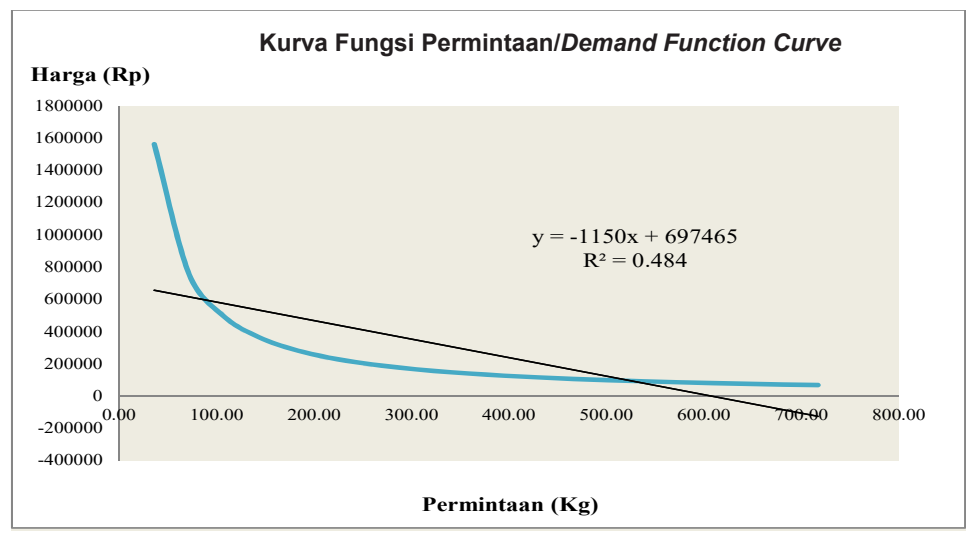

Gambar 2. Kurva Fungsi Permintaan Effect on Production (EOP) Aktifitas Penangkapan Ikan Karang di Kawasan Konservasi Gili Matra.

Figure 2. Demand Function Curve of Effect on Production (EOP) of Coral Fishing Activities in the Gili Matra Conservation Area. 


\section{b. Nilai Kegunaan Sebagai Wisata Pantai}

Nilai ekonomi ekosistem TWP Gili matra yang terdiri dari mangrove, terumbu karang dan biota lainnya mempunyai nilai manfaat langsung sebagai salah satu daya tarik wisata bagi wisatawan baik mancanegara maupun domestik. Penilaian manfaat ekonomi wisata didekati dengan menggunakan teknik Travel Cost Method (TCM). Hasil regresi linear berganda antara jumlah kunjungan dengan peubah biaya. menunjukkan fungsi permintaan sebagai berikut:

$$
f(Q)=-4 E+14 x+3 E+14
$$

Dari fungsi di atas dapat diperoleh kurva permintaan terhadap wisata tersebut dapat dilihat pada Gambar 3.

Nilai ekonomi TWP Gili Matra berdasarkan fungsinya sebagai penyedia jasa wisata dapat dihitung dengan cara mencari besaran surplus bagi konsumen sebesar Rp8.592.614/orang. Berdasarkan analisis kesesuaian dan daya dukung, luas pantai yang sesuai untuk kegiatan wisata pantai di TWP Gili Matra sebesar 2,6 ha. Daya dukung kawasan untuk wisata pantai sebanyak 75 orang. Besarnya biaya perjalanan per orang untuk menikmati wisata pantai kawasan Gili matra rata-rata sebesar Rp8.592.614. Dengan demikian, dapat dihitung nilai ekonomi kawasan sebagai penyedia wisata pantai sebesar Rp1.102.165.479/ tahun.

\section{NILAI KEGUNAAN TAK LANGSUNG SUMBER DAYA PESISIR DAN LAUT TWP GILI MATRA}

\section{a. Nilai Kegunaan Sebagai Pelindung Pantai}

Salah satu manfaat tidak langsung ekosistem mangrove dan terumbu karang adalah sebagai penghalang (barrier) bagi wilayah pesisir dari ombak atau gelombang besar dimana barrier tersebut dapat menahan serta memperkecil energi gelombang dari laut lepas yang masuk ke wilayah pesisir. Reduksi energi tersebut dapat mengurangi dampak abrasi dan kerusakan lain yang terjadi di kawasan pesisir. Perhitungan nilai manfaat ini dapat dilakukan dengan menggunakan biaya pengganti, sebagai dasar standar biaya per meter kubik yang digunakan sebagai material pemecah gelombang oleh Kementerian Pekerjaan Umum dimana kisaran harga per meter kubik yaitu Rp500.000 Rp600.000. Berdasarkan pernyataan dari Santoso (2005) bahwa untuk menghitung nilai pengganti ekosistem sebagai fungsi ini hanya sepertiga dari pembangunan breakwater. Panjang garis pantai di kawasan TWP Gili Matra yang terlindung oleh ekosistem karang sebesar 17.398,3 meter, sehingga nilai manfaat dari ekosistem karang dengan manfaat sebagai pelindung pantai sebesar Rp9.569.065.000/tahun.

Kemudian fungsi tidak langsung lainnya dari ekosistem mangrove yaitu sebagai penyimpan karbon. Hasil penelitian sebelumnya menyatakan bahwa rata-rata karbon yang tersimpan pada batang, daun, akar dan kayu mati sebesar 373 $\mathrm{MgC} / \mathrm{ha}$. Sebaran ekosistem mangrove di kawasan Gili Matra yang berada pada kondisi baik seluas 1,81 ha. Sehingga dapat diprediksi nilai serapan karbon yang tersimpan pada ekosistem mangrove mencapai $0,6751 \mathrm{MgC} / \mathrm{ha}$. Simpanan Karbon tersebut tergolong tinggi. Apabila diperhitungkan dengan nilai moneter sebesar US \$16,5/metrik ton C (Rp13.500/1 USD) sehingga menghasilkan nilai sebesar Rp150.378,54/tahun.

\section{b. Nilai Sosial TWP Gili Matra}

Nilai Willingness to Pay (WTP) tiap anggota masyarakat untuk keberadaan dan kelestarian sumber daya rata-rata sebesar Rp104.730/

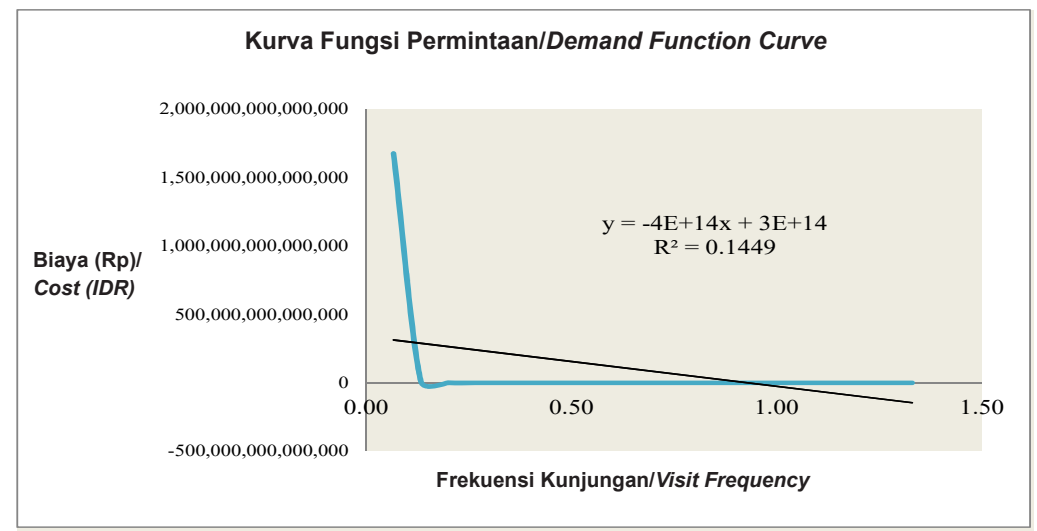

Gambar 3. Fungsi Permintaan Wisata di Kawasan TWP Gili Matra. Figure 3. Function of Tourist Demand in The Gili Matra TWP Area. 
tahun. Nilai ini mengambarkan bahwa kesediaan berpartisipasi masyarakat dalam kawasan rehabilitasi dan wisata bahari. Bentuk partisipasi yang dinilaikan (preferensi) dalam angka tersebut mencakup penilaian terhadap keindahan, nilai spiritual dan budaya, keanekaragaman, arti penting sumber daya. Adapun bentuk kesediaannya berupa kesediaan ikut melestarikan sumber daya, berkorban tenaga serta ikut iuran untuk kegiatan menjaga keberadaan dan kelestarian sumber daya di TWP Gili Matra.

Adapun nilai jasa sosial budaya sumber daya ekosistem pesisir di TWP Gili Matra sebesar Rp4.460.856.979/tahun. Faktor yang berpengaruh terhadap kesediaan masyarakat membayar untuk keberlangsungan eksositem di TWP Gili Matra adalah tingkat pendapatan, umur, pendidikan, dan jumlah anggota keluarga.

\section{NILAI PILIHAN (OPTION VALUE)}

Penilaian fungsi fisik ekosistem mangrove dan terumbu karang dilakukan dengan menggunakan pendekatan Benefit Transfer. Fungsi ekologi mangrove dan terumbu karang merupakan manfaat pilihan keanekaragaman hayati, fungsi ini yang dilakukan penilaian. Estimasi penilaian komponen mangrove dan terumbu karang digunakan dengan pendekatan yang menyebutkan bahwa manfaat pilihan ekosistem mangrove sebagai keanekaragaman hayati adalah sebesar US\$ 15/ ha atau sebesar Rp202.500/ha (Rp 13.500/1 USD). Sementara itu nilai terumbu karang sebagai keaneragaman hayati sebesar US\$ 100/Ha atau sebesar Rp1.350.000/ha (Rp13.500/1 USD). Kawasan TWP Gili Matra memilki luas ekosistem mangrove sebesar 15.030,09 ha dan terumbu karang seluas 8.016,21 ha. Sehingga dapat dihitung bahwa nilai manfaat pilihan ekosistem sebagai penyedia keanekaragaman hayati yaitu untuk ekosistem mangrove sebesar Rp3.043.593.225/tahun dan nilai terumbu karang sebesar Rp10.821.883.500/ tahun.

\section{PENUTUP}

Berdasarkan hasil penelitian diperoleh nilai ekonomi total sumber daya terumbu karang dan mangrove TWP Gili Matra adalah sebesar Rp29.148.844.979,54/tahun, yang dihitung dari nilai kegunaan langsung Rp1.253.295.897/ tahun, nilai kegunaan tidak langsung Rp14.030.072.357,54/tahun dan nilai pilihan Rp13.865.476.725.
Nilai kegunaan langsung diperoleh dari nilai pemanfaatan ikan karang berdasarkan data tersebut maka diketahui total nilai manfaat langsung sumber daya ikan karang di TWP Gili Matra yaitu sebesar Rp151.130.418/Ha/Tahun. Dengan demikian, dapat dihitung nilai ekonomi kawasan sebagai penyedia wisata pantai sebesar Rp1.102.165.479/tahun.

Nilai kegunaan tidak langsung dapat diperoleh dari nilai manfaat ekosistem karang sebagai pelindung pantai dengan nilai sebesar Rp 9.569.065.000/tahun. Nilai serapan karbon yang dapat diperoleh dari ekosistem mangrove, apabila diperhitungkan dengan nilai moneter sebesar US\$ 16,5/metrik ton C (1 USD=13.500) sehingga menghasilkan nilai sebesar Rp150.378,54 per tahun. Sementara itu nilai jasa sosial budaya sumber daya ekosistem pesisir di TWP Gili Matra sebesar Rp. 4.460.856.979/tahun.

Nilai pilihan yang terdapat pada ekosistem mangrove dan terumbu karang sebagai penyedia keanekaragaman hayati yaitu untuk ekosistem mangrove sebesar Rp3.043.593.225/tahun dan terumbu karang sebesar Rp10.821.883.500/tahun.

Sumber daya di TWP Gili Matra mempunyai nilai ekonomi dan kualitas ekologi yang penting bagi pemerintah maupun masyarakat. Pemerintah (Pusat, Provinsi dan Daerah) harus mengikutsertakan peran aktif masyarakat guna melakukan pengendalian dan pengawasan secara terpadu dalam pemanfaatan sumber daya alam (terumbu karang dan mangrove) TWP Gili Matra. Kegiatan tersebut merupakan salah satu bentuk dukungan dalam pembangunan wilayah yang berkelanjutan.

\section{UCAPAN TERIMA KASIH}

Pada kesempatan ini penulis mengucapkan terima kasih kepada pihak-pihak yang telah membantu peneliti selama pengumpulan data, rekan-rekan tim peneliti lingkup BBRSEKP, rekan-rekan dosen dan mahasiswa dari Fakultas Perikanan dan IImu Kelautan, Universitas Mataram.

\section{DAFTAR PUSTAKA}

Adrianto, L. 2006. Sinopsis Pengenalan Konsep dan Metodologi Valuasi Ekonomi Sumber daya Pesisir dan Laut. PKSPL-IPB. Bogor.

As'ad, M. 2004. Psikologi Industri. Liberty: Yogyakarta. 
Barton, D.N. 1994. Economic Factors and Valuation of Tropical Coastal Resources. Center for Milij $\varnothing$-og Ressurrtudier Report 14/94, Bergen, Norway.

Cesar, H.S.J. 2000. Coral Reefs: Their Functos, Threats and Economic Value. Page 14-39 in H. Cesar, ed. Collected Essays on The Economics of Coral Reef. Coral Reef Degradation in the Indian Ocean Program, Kalmar University, Kalmar, Sweden.

Dinas Kelautan dan Perikanan Provinsi NTB. 2015. Potensi Daerah Kelautan dan Perikanan. DKP Prov. Nusa Tenggara Barat.

Fauzi, A. 2000. Kebijakan Pengelolaan Sumber daya Pesisir. Institut Pertanian Bogor. Bogor.

Fauzi, A. 2004. Ekonomi Sumber Daya Alam dan Lingkungan. Gramedia Pustaka Utama. Jakarta.

Grigalunas, T. A. and R. Congar. 1995. Environmental economics for Integrated Coastal Area Management: Valuluation Methods and Policy Instruments. UNEP Regional Seas Reports and Studies No. 164. UNEP.

Kementerian Kelautan dan Perikanan. 2015. Valuasi Ekonomi dan Daya Dukung Sumber daya Kawasan Konservasi Nasional. Direktorat Kawasan Konservasi dan Jenis Ikan-KKP RI. Jakarta.

Matulis, B.S. 2014. The Economic Valuation of Nature: A Question of Justice?. Journal Ecological Economies 75(1): 40-47.

McCauley, D. 2006. Selling Out on Nature. Journal of Nature 443(1): 27-28.

Muqsith, A. 2015. Valuasi Ekonomi Sumber daya Alam Pantai Sidem. Samakia-Jurnal IImu Perikanan. Volume 6, No. 2, Agustus 2015.

Nilwan. 2003. Spesifikasi Teknis Penyusunan Neraca dan Valuasi Ekonomi Sumber daya Alam Pesisir dan Lautan. Pusat Survei Sumber daya Alam Laut Baksurtanal. Bogor

Pearce, D.W. and K.R. Turner. 1990. Economics of Natural Resources and The Environment. Harvester Wheatsheaf, London.

Pujiyono, A. 2013. Pengaruh Umur, Jumlah Tanggungan Keluarga, Luas Lahan, Pendidikan, Jarak Tempat Tinggal Pekerja Ke Tempat Kerja, dan Keuntungan Terhadap Curahan Waktu Kerja Wanita Tani Sektor Pertanian di Desa Tajuk, Kec. Getasan, Kab. Semarang. Diponegoro Journal of Economics. Volume 2 Nomor 3.
Putera, F.H.A. dan A.E. Sallata. 2015. Valuasi Ekonomi Sumber daya Di Teluk Palu, Kota Palu, Provinsi Sulawesi Tengah. Jurnal Kebijakan Sosek KP Vol.5 No. 2 Tahun 2015.

Santoso. 2005. Valuasi Ekonomi Ekosistem Hutan Mangrive di Kawasan Pondok Bali, Desa Logonwetan, Kecamatan Legonkulon, Kabupaten Subang, Jawa Barat. Bogor. Institut Pertanian Bogor.

Shrestha, R.K. and J.B. Loomis. 2003. Meta-Analytic Benefit Transfer of Outdoor Recreation Economic Values: Testing Out-of-Sample Convergent Validity. Environmental and Resource Economics 25:79-100, 2003. Kluwer Academic Publishers. Netherlands.

Spurgeon, J.P.G. 1992. The Economic Valuation of Coral Reefs. Mar. Pollut. Bull. 24 (11): 529-536.

Suharti, R.S. 2014. Baseline Survey Kesehatan Terumbu Karang dan Ekosistem Terkait di TWP Gili Matra. COREMAP-CTI, Pusat Penelitian Oseanografi-LIPI. Jakarta.

Suparmoko, M. 2009. Pedoman Penilaian Ekonomi Sumber daya Alam dan Lingkungan (Konsep dan Metode Perhitungan), Edisi Pertama, BPFE, Yogyakarta.

Yaping, D. 1999. The Value of Improved Water Quality for Recreation in East Lake, Wuhan China. EEPSEA, Singapore.

\section{Peraturan Perundangan}

Keputusan Menteri Kelautan dan Perikanan Republik Indonesia Nomor Kep.67/Men/2009 tentang Penetapan Kawasan Konservasi Perairan Nasional Pulau Gili Ayer, Gili Meno, dan Gili Trawangan di Provinsi Nusa Tenggara Barat.

Keputusan Menteri Kelautan dan Perikanan Republik Indonesia Nomor 57/Kepmen-KP/2014 tentang Rencana Pengelolaan dan Zonasi Taman Wisata Perairan Pulau Gili Ayer, Gili Meno dan Gili Trawangan di Provinsi Nusa Tenggara Barat Tahun 2014-2034. 